\title{
Uzaktan Eğitim Sürecinde Beden Eğitimi ve Spor Öğretmenlerinin Ders Verimliliğine İlişkin Görüşlerinin İncelenmesi
}

\author{
Numan Bahadır KAYIŞOĞLU 1 (D), Mehmet ÇETIN 2 (D), \\ Seda BOSTANOĞLU ${ }^{3}$ (iD), Hasibe Çİ'³ \\ ${ }^{1}$ Karabük Üniversitesi, Hasan Doğan Beden Eğitimi ve Spor Yüksekokulu, KARABÜK \\ ${ }^{2}$ Safranbolu Fatih Sultan Mehmet Anadolu Lisesi, MEB, KARABÜK \\ ${ }^{3}$ Karabük Üniversitesi, Lisansüstü Eğitim Enstitüsü, KARABÜK
}

Araştırma Makalesi

DOI:10.53434/gbesbd. 1007546

Öz

COVID-19 salgınıyla dünya genelinde yüz yüze eğitim sisteminin yerini uzaktan eğitim sisteminin aldığı görülmektedir. Bu süreç uzaktan eğitimle yürütülen beden eğitimi ve spor dersinin verimliliği sorgulanır hale getirmiștir. Bu bakımdan araştırmada beden eğitimi ve spor öğretmenlerinin uzaktan eğitim sürecinde işledikleri derslerin verimliliklerinin incelenmesi amaçlanmıştır. Nitel araştırma kapsamında fenomenoloji deseni kullanılarak yürütülen araștırmada amaçlı örneklem yöntemlerinden maksimum ölçüt örnekleme metodu kullanılmıştır. Araştırmaya 14 beden eğitimi ve spor öğretmeni katılmıştır. Yarı yapılandırılmış görüşme tekniğiyle elde edilen verilerin analizinde içerik analizi kullanılmıștır. Araştırmada dersin uzaktan eğitim sürecinin verimliliğine, ders verimliliğini arttırmaya yönelik uygulamalara, uzaktan eğitimin tercih edilme durumuna ve son olarak uzaktan eğitime yönelik talep ve önerilerine ilişskin bulgulara ulaşılmıştır. Araştırmanın sonucunda etkileșimsizlik, öğrenci devamsızlı̆̆ı, uygulamalı konuların işlenmesine elverişsiz olması, öğrencilerin bilgisayar ve internet erişimi bakımından farklılıklarının olması, öğretmenlerin uzaktan eğitime hazırlıksız olmaları ve teknopedagojik eğitim yetersizlikleri gibi nedenlerden dolayı uzaktan eğitimle yürütülen beden eğitimi ve spor derslerinin verimsiz olduğu sonucuna ulaşılmıştır.

Anahtar sözcükler: Uzaktan eğitim, Beden eğitimi ve spor öğretmeni, Beden eğitimi ve spor, Ders verimliliği 


\title{
Investigation of Physical Education and Sports Teachers' Views on Lesson Efficiency in Distance Education Process
}

\begin{abstract}
With the COVID-19 epidemic, it is seen that the face-to-face education system has been replaced by the distance education system worldwide. This process has made the efficiency of the physical education and sports course carried out with distance education questionable. In this respect, it was aimed to examine the efficiency of the lessons taught by physical education and sports teachers in the distance education process. The maximum criterion sampling method, one of the purposeful sampling methods, was used in the research carried out using the phenomenology design within the scope of qualitative research. 14 physical education and sports teachers participated in the research. Content analysis was used in the analysis of the data obtained by the semi-structured interview technique. In the research, the findings related to the efficiency of the distance education process of the course, the applications to increase the efficiency of the course, the preference of distance education, and finally the demands and suggestions for distance education were obtained. As a result of the research, it has been concluded that physical education and sports lessons conducted with distance education are inefficient due to reasons such as lack of interaction, student absenteeism, inconvenience to the teaching of applied subjects, students' differences in terms of computer and internet access, teachers' unpreparedness for distance education and technopedagogical education inadequacies.
\end{abstract}

Keywords: Distance education, Physical education and sport teacher, Physical education and sport, Lesson efficiency

\section{Giriş}

Yeryüzünde yaşamın başlamasıyla birlikte insanlık, çeşitli doğal afetlerle karşı karşıya kalmış ve bu afetlerden kurtulmak için ilgili alanlarda bilgi sahibi olarak ve kapsamlı bir eğitim alarak afetlere karşı direnmeyi amaçlamıştır. Yirmi birinci yüzyılın başında bu felaketlere bir de COVID-19 salgını eklenmiştir. Bu salgın Aralık 2019'da ortaya çıkan ve ilk vakalarını Çin'in Wuhan kentinde gösteren bir solunum yolu hastalığıdır (Wang, Liu, Hao ve Guo 2020). Buna göre tüm dünyayı etkisi altına alan COVID-19 salgını; günümüz eğitim, araştırma, hizmet ve küresel eğitim sistemleri derinden etkilenmiştir. Küresel ölçekte insanların daha fazla COVID-19'dan etkilenmemesi için belirli kısıtlamalara ek olarak, Nisan 2020'de okulların kapatılma uygulaması zirveye ulaşmıștır. Dünyanın yaklaşık \%91'ine tekabül eden 1,6 milyar öğrenci bu süreçten etkilenmiştir (Devaney, Shimshon, Rascoff ve Maggioncalda, 2020). Bu süreçte halk sağlığının korunması ve aynı zamanda eğitim ve öğretime de devam edilebilmesi için uzaktan eğitim sistemi yaygınlaşmaya başlamıștır. Bu duruma bağlı olarak mevcut sürecin doğal sonucu olan değişimlerle ilgili literatürde birçok araştırma ve çalışma yapılmıştır. Yapılan araştırmalara göre uzaktan eğitim ile ilgili öğrenme süresinin uzadığı, derslerde gecikmelerin olduğu, öğretmenlerin uzaktan eğitim sistemini tam anlamıyla benimsemediği tespit edilmiştir. Öte yandan uzaktan eğitim sisteminin geliştirilmesi durumunda daha verimli olabileceği sonuçlar arasında yer almaktadır (Chen, Peng, Yin, 
Rong, Yang ve Cong, 2020; Jena, 2020; Moralista ve Oducado, 2020). Öğretmen-öğrenci etkileşimi, derslerin belirli öğretim modelleriyle işlenmesi gibi durumlar pandemi nedeniyle büyük bir değişime maruz kalmıştır. Bu nedenle öğrencilerin alışılagelmiş yüz yüze eğitim sisteminden, uzaktan eğitim sistemine geçmeleri, motivasyon ve başarı düzeylerinde bir değişikliğe neden olmuştur (Konecki, 2020). Öğrencilerin duygu durumlarına bağlı olarak, aynı șekilde öğretmenlerin de motivasyon kaybına uğramaları ihtimaller arasında sayılabilmektedir (Kurnaz, Kaynar, Barışık ve Doğrukök 2020).

Beaudoin'e (1990) göre; uzaktan eğitim sürecinde öğretmenlere büyük görev düşmektedir. Bu görevlerden bir tanesi, mesafeye ve teknoloji kullanımı sırasında ortaya çıkan problemlere rağmen, öğrencilerin öğrenme potansiyellerini artırmak ve iyi bir şekilde öğrenme sürecine dâhil olmalarını sağlayabilmektir. Buna benzer olarak uzaktan eğitim sisteminde öğretmenler; sınıf becerilerini geliştirmenin yanı sıra, teknik uzmanlık, sorun gidericilik ve motivatörlük gibi özelliklere sahip olmalıdırlar (Mood, 1995). Eğitimin COVID-19 şartlarında da sürdürülebilmesi için yüz yüze eğitim sistemini etkileyen değişiklikler meydana gelmiştir. Salgının daha fazla yayılmasını engellemek amacıyla "Öğrenmeyi Durdurmadan Sınıfları Askıya Alma" durumu ortaya çıkmıştır (Zhang, Wang, Yang ve Wang 2020). Böylece öğrenmenin asıl gerçekleştiği sınıf ortamı, uzaktan eğitim vasıtasıyla online sınıflara taşınmıştır. Ancak bu değişim, beden eğitimi ve spor dersi özelinde öğretmen-öğrenci etkileşimini tam olarak sağlayamadığı gerekçesiyle verimsiz olarak görülmektedir (Adnan ve Anwar, 2020). Benzer şekilde Pierre'nin (1998) araştırmasında da uzaktan eğitim sisteminin daha çok geliştirilmesi durumunda beden eğitimi ve spor ders verimliliğinin artacağı ifade edilmektedir. Bu doğrultuda "uzaktan eğitim sürecinde beden eğitimi ve spor öğretmenlerinin ders verimliliğine ilişkin görüşlerinin incelenmesi" adlı araştırmada; öğretmenlerin işlenen ders verimliliklerine ilişkin görüşlerinin alınması ve problemlere karşı olası çözüm önerilerinin belirlenmesi amaçlanmıştır.

\section{Yöntem}

Bu bölümde araştırmanın model ve deseni, katılımcılar, verilerin toplanması, veri toplama süreci, verilerin analizi, geçerlik ve güvenirlik ile ilgili bilgilere yer verilmiştir.

\section{Araştırmanın Modeli}

Creswell'e (2013) göre nitel araştırma; bireyler ile direkt olarak iletişime geçerek, bireylerin kendi ortamlarında davranış ve hareketlerinin daha iyi gözlemlenebilmesi sayesinde bilgileri toplamaktır. Bu durum elde edilen verilerin güvenirliğini artırmaktadır. $\mathrm{Bu}$ nedenle araştırma, nitel araştırma kapsamında fenomenoloji (olgu bilim) deseni kullanılarak yürütülmüştür. Fenomenolojik araştırmalar, birkaç kişinin bir fenomen veya kavramla ilgili deneyimlerin ortak anlamını keşfeder (Creswell, 2013).

Gordon'a (1975) göre bir araştırmacıyla yüz yüze iletişim kurmak, katılımcıların yanıtlarını daha fazla motive edebilir (Louise ve While, 1994). Bu nedenle daha doğru ve detaylı verilerin elde edilebilmesi amacıyla nitel araştırma tekniklerinden "yarıyapılandırılmış görüşme" tekniği kullanılmıştır. Yarı yapılandırılmış görüşme tekniği, nitel 
araştırmalarda en sık kullanılan yöntemlerden biridir (Dicicco- Bloom ve Crabtree, 2006). Bu sayede yarı yapılandırılmış görüşme tekniğinin çok yönlü ve esnek olması, popüler bir veri toplama yöntemi olmasını sağlamaktadır (Kallio, Pietila, Johnson ve Kangasniemi, 2016).

\section{Katılımcilar}

Amaçlı örnekleme yöntemi, araştırmacılara kendi bilgi, deneyim ve gözlemlerinden yola çıkarak örneklemlerini seçme fırsatı sunmaktadır (Ural ve Kılıç, 2005). Araştırmanın katılımcıları amaçlı örneklem yöntemlerinden maksimum ölçüt örnekleme metodu kullanılarak belirlenmiştir. Ölçüt örneklemede araştırmada belirli niteliklere sahip kişiler gözlem birimini oluşturabilir ve ölçütü karşılayan birimler örnekleme dâhil edilir (Büyüköztürk, Çakmak, Akgün, Karadeniz ve Demirel, 2018). Katılımcıların belirlenmesinde; eğitim durumu (lisans ve lisansüstü eğitim), çalışllan kurum (ortaokullise), hizmet yılı (0-10, 11-20, 21 ve üzeri) gibi ölçütler göz önünde bulundurulmuştur. Bu sayede farklı kurum, eğitim durumu ve hizmet deneyimi ölçütlerine sahip beden eğitimi ve spor öğretmenlerinin uzaktan eğitim sürecinde ders verimliliğine ilişkin görüşlerini tespit etmek amaçlanmıştır. Araştırmaya yukarıda bahsedilen ölçütler doğrultusunda gönüllü 14 beden eğitimi öğretmeni katılmıştır. Katılımcılara ilişkin demografik bilgiler tablo 1 'de verilmiştir.

Tablo 1. Katılımcıların ait demografik özellikler

\begin{tabular}{lllcll}
\hline Katılımcı Kodu & Cinsiyet & Eğitim Düzeyi & $\begin{array}{l}\text { Hizmet } \\
\text { Yllı }\end{array}$ & $\begin{array}{l}\text { Çalışlan } \\
\text { Kurum }\end{array}$ & $\begin{array}{c}\text { Çalışlan Kurum } \\
\text { Türü }\end{array}$ \\
\hline 01 & E & Lisans & 11 & Ortaokul & Devlet Okulu \\
O2 & E & Lisans & 9 & Ortaokul & Devlet Okulu \\
O3 & K & Lisans & 25 & Ortaokul & Devlet Okulu \\
L4 & E & Lisans & 23 & Lise & Devlet Okulu \\
O5 & E & Lisans & 23 & Ortaokul & Devlet Okulu \\
L6 & E & Lisans & 25 & Lise & Devlet Okulu \\
O7 & E & Lisans & 24 & Ortaokul & Devlet Okulu \\
L8 & E & Lisansüstü & 21 & Lise & Devlet Okulu \\
L9 & E & Lisansüstü & 16 & Lise & Devlet Okulu \\
L10 & E & Lisansüstü & 16 & Lise & Devlet Okulu \\
011 & E & Lisansüstü & 13 & Ortaokul & Devlet Okulu \\
O12 & E & Lisans & 6 & Ortaokul & Özel Okul \\
013 & E & Lisans & 10 & Ortaokul & Devlet Okulu \\
L14 & E & Lisans & 30 & Lise & Devlet Okulu \\
\hline
\end{tabular}

\section{Verilerin Toplanması}

Araştırmada verilerin toplaması amacıyla yarı yapılandırılmış görüşme tekniği uygulanmıştır. Yarı yapılandırılmış görüşme tekniğinin araştırmada derinlemesine bilgi edinme, görüşülenin kendini ifade etmesi, analiz kolaylığının olması gibi olumlu yönleri bulunmaktadır (Büyüköztürk ve diğerleri, 2018). Bu kapsamda görüşme formu araştırmacılar tarafından hazırlanmıştır. Bununla birlikte beden eğitimi ve spor alanında 12 yıllık akademik tecrübeye sahip olan bir uzman tarafından görüşme formu 
değerlendirilmiştir. Değerlendirmenin sonucunda görüşme maddelerinde düzenlemeler gerçekleştirilmiştir. Görüşme formunda iki bölüm yer almakta olup birinci bölümde katılımcılara ait demografik bilgilerin yer aldığı sorular; ikinci bölümde ise uzaktan eğitim sürecinde beden eğitimi ve spor öğretmenlerinin ders verimliliğine ilişkin görüşlerini belirlemesini sağlayacak sorular yer almaktadır. Araştırmada yer alan görüşme soruları şu şekilde sıralanmıştır;

- Ders verimliliği konusundaki düşünceleriniz nelerdir? Uzaktan eğitimde kendi dersinizin verimli geçtiğini düşünüyor musunuz? Neden? Uzaktan eğitimde ders verimliliğinizi etkileyen en önemli unsurlar nelerdir?

- Uzaktan eğitimde ders verimliliğini arttırmaya yönelik gerçekleştirdiğiniz uygulamalarınız nelerdir?

- Yüz yüze eğitim sistemi ile uzaktan eğitim sistemini karşılaştırdığınızda hangisini tercih edersiniz? Neden?

- Mevcut uzaktan eğitim sistemi için beden eğitimi ve spor dersi açısından bir öneri getirmeniz istense ne önerirdiniz? Talep ve önerileri görüşleriniz nelerdir?

\section{Veri Toplama Süreci}

Çalışma kapsamında öncelikle Bartın Üniversitesi'nin Etik Kurulu'na başvuru yapılarak, Etik Kurul Onay Belgesi (2021-SBB-0041 protokol no 16.02.2021 tarih ve 2 nolu sayılı) alınmıştır.

Araştırmacılar tanıdıkları arasında yer alan ve farklı illerde görev yapan beden eğitimi öğretmenleri ile iletişime geçmiştir. Ayrıca beden eğitimi ve spor öğretmenlerinin yer aldığı çeşitli platform ve sosyal medya grupları üzerinden araştırma hakkında duyuru ve bilgilendirme yapılmıştır. Ölçüt ve gönüllülük kriterleri doğrultusunda araştırmaya gönüllü olarak katılmayı beyan eden 14 beden eğitimi ve spor öğretmeni katılımcı olarak belirlenmiștir. Görüșmeler Zoom programı üzerinden yapılmıș ve her görüșme kayıt altına alınmıștır. Araştırmada, katılımcılara uzaktan eğitim sürecinde derslerin verimliliği ile ilgili toplam altı soru sorulmuş ve soruların yanıtlanması istenmiştir. En uzun görüşme 33 dakika, en kısa görüşme 8 dakika sürmüștür. Tüm katılımcılarla toplam görüşme süresinin ortalaması 15 dakika sürmüştür.

Görüşmelerden önce katılımcılarla iletişime geçilmiş ve çalışmanın konusu hakkında bilgi verilmiştir. Görüşme sırasında katılımcılardan hazır olduklarına ilişkin yanıt alındıktan sonra yaş, cinsiyet ve ders verme süresi gibi demografik bilgiler not edilmiş ve görüşme sorularına geçilmiştir. Aynı zamanda video ve ses kayıtlarının yalnızca akademik bir çalışmada kullanılması için tüm katılımcılardan gerekli izinler alınmıştır.

\section{Verilerin Analizi}

Araştırmanın veri analizinde nitel araştırma kapsamında içerik analizi yöntemi kullanılmıştır. İçerik analizi; metinlerde yer alan kelime, kavramların anlam ve ilişkileri tespit ve analizi sayesinde çıkarımlarda bulunmayı sağlar (Büyüköztürk ve diğerleri, 
2018). Veriler analiz edilmeden önce görüşme videoları yazına aktarılmıştır. Katılımcılar çalıştıkları lise ve ortaokul değişkenlerine göre 0 ve L (O: ortaokul, L: lise) harfleriyle kodlanmıştır. Bunun yanı sıra görüşme sırasına göre 1, 2, 3 şeklinde sıra numarasıyla belirtilmiştir. Katılımcı verilerine ait yazına aktarılan bütün formlar 3 araștırmacı tarafından birer birer okunmuştur. Katılımcı görüşlerine ait farklı ve benzer kavramlar üzerinden tema, alt tema ve kodlar belirlenmiștir. Kodlara ilişkin frekanslar sayıları belirlenerek bulgular bölümündeki tablolarda sunulmuştur.

\section{Geçerlilik ve Güvenilirlik}

Araştırmada geçerlik (inandırıcılık ve aktarılabilirlik) ve güvenirlik (tutarlılık) kapsamında bazı yöntemler uygulanmıştır (Yıldırım ve Şimşek, 2018). Bu kapsamda iç geçerlik, bilimsel bir araştırmada yapılan gözlem ve ölçümlerin gerçeklikle ilişkisini ifade etmektedir. İç geçerliliğin sağlanması adına araştırmacılar tarafından yapılan iki farklı kavramsallaştırma sonuçları karşılaştırılmış buna göre; benzerlikler ve farklılıklar tespit edilerek daha net kavramlara ulaşılmıştır. Dış geçerliliğin sağlanmasında örneklemi belirlemede amaçlı örnekleme yöntemi kullanılmıştır. İnandırıcılık için katılımcıların teyidi alınmıștır.

Buna göre araştırma verileri raporlaştırıldıktan sonra gönüllü öğretmenlerle "teyit toplantısı" yapılmıştır. Bununla birlikte bulgular bölümünde betimlemelere yani katılımcılara ait doğrudan alıntılara yer verilerek aktarılabilirlik sağlanmıştır. Katılımcılardan 38 sayfalık veri elde edilirken, toplamda 37 koda ulaşılmıştır.

Miles ve Huberman'a göre (1994), veri setleri iki farklı araştırmacı tarafından kullanılarak kodlama yapıldığı zaman tanımların daha keskin olması öngörülmektedir. Dolayısıyla kodların hangi anlama geldiği ve kullanılan veri parçalarının hangi koda ait olduklarıyla ilgili ortak görüşün olması önem arz etmektedir. Herhangi bir uzlaşmazlık durumunda ise tanımların düzeltilmesi gerektiği yönünde sonuca ulaşılmaktadır. Üzerinde uzlaşılan kod sayısının toplam uzlaşılan ve uzlaşılamayan kod sayısına bölünmesiyle kodlayıcılar arası güvenilirlik oranı hesaplanabilir (Miles ve Huberman, 1994). Bu oranın \%80'e yakın olması, hatta verilerin büyüklügüne göre \%90'dan fazla olması önerilmektedir. Bu bilgiler ışığında, çalışmanın güvenirlik hesaplaması yapılmış ve bu oran \%92 olarak belirlenmiştir.

\section{Bulgular}

Bu bölümde araştırmanın "Beden eğitimi ve spor dersinin verimliliği açısından uzaktan eğitim sürecine ilişkin öğretmen görüşlerinin belirlenmesi” amacına yönelik yapılan görüşmeler sonucundaki bulgular yer almaktadır. Elde edilen veriler tablo ve doğrudan alıntılar şeklinde sunulmuştur. 
Tablo 2. Uzaktan eğitimde beden eğitimi ve spor dersinin verimliliğine ilişkin öğretmen görüşleri

\begin{tabular}{|c|c|c|c|c|}
\hline Tema & Alt Tema & Kod & Katılımcı & $f$ \\
\hline \multirow{14}{*}{$\begin{array}{l}\text { Beden eğitimi } \\
\text { ve spor dersinin } \\
\text { uzaktan eğitim } \\
\text { sürecinin } \\
\text { verimliliği }\end{array}$} & \multirow{4}{*}{$\begin{array}{l}\text { Öğrenciye } \\
\text { İlişkin }\end{array}$} & Etkileşimsizlik & $\begin{array}{l}\text { 03, 05, L6, O7, L8, 011, 012, } \\
\text { 013, L14 }\end{array}$ & 9 \\
\hline & & Devamsızlık & $\begin{array}{l}\text { 01, L4, L6, L8, L10, 012, 013, } \\
\text { L14 }\end{array}$ & 8 \\
\hline & & Kamera açılmaması & 05, L6, O7, L8, L9, 012 & 6 \\
\hline & & Toplam & & 23 \\
\hline & \multirow{3}{*}{$\begin{array}{l}\text { Ders } \\
\text { verimliğine } \\
\text { ilişkin }\end{array}$} & $\begin{array}{l}\text { Uygulamalı konularda } \\
\text { verimsizlik }\end{array}$ & $\begin{array}{l}\text { 01, 02, 03, L4, 05, 07, L8, } \\
\text { 011, 013, L14 }\end{array}$ & 10 \\
\hline & & $\begin{array}{l}\text { Teorik konularda } \\
\text { verimlilik }\end{array}$ & 03, L6, L8, L9, L10, 011, 013 & 7 \\
\hline & & Toplam & & 17 \\
\hline & \multirow{3}{*}{$\begin{array}{l}\text { Firsat } \\
\text { eşitsizliğine } \\
\text { ilișkin }\end{array}$} & İnternetsizlik & 01, 02, 03, L4, L8, L9, 012 & 7 \\
\hline & & Tablet, PC eksikliği & 02, 05, L8 & 3 \\
\hline & & Toplam & & 10 \\
\hline & \multirow{4}{*}{$\begin{array}{l}\text { Öğretmen } \\
\text { teknopedagojik } \\
\text { eğitim } \\
\text { yeterliğine } \\
\text { ilişkin }\end{array}$} & Hazırlıksız olunması & $04,03,07,011,012$ & 5 \\
\hline & & $\begin{array}{l}\text { Programların } \\
\text { bilinmemesi }\end{array}$ & 05, L6, 011, 012 & 4 \\
\hline & & Toplam & & 9 \\
\hline & & Genel toplam & & 59 \\
\hline
\end{tabular}

Tablo 2'de görüldüğü gibi "beden eğitimi ve spor dersinin uzaktan eğitim sürecinin verimliliği" teması yer almaktadır. Bu tema altında "öğrenciye ilişkin", "ders verimliğine ilişkin", "fırsat eşitsizliğine ilişkin" ve "öğretmen teknopedagojik eğitim yeterliğine ilişkin" dört alt temaya ulaşılmıştır. Öğretmen görüşleri neticesinde beden eğitimi ve spor derslerinin uzaktan eğitim sürecinin verimsizliğini vurgulayan kodlara ulaşılmıştır. Büyük çoğunluğu öğrenciye ilişkin alt temada, etkileşimsizlik; ders verimliliğine ilişkin alt temada, uygulamalı konularda verimsizlik; fırsat eșitsizliğine ilișkin alt temada, internetsizlik; son olarak öğretmenlerin teknopedagojik eğitim yeterliğine ilişkin alt temada, hazırlıksız olunması kodlarından oluşmaktadır. Uzaktan eğitim sürecinde beden eğitimi ve spor dersinin teorik konularının işlenmesinde ders verimliliğine ilişkin bazı öğretmenlerin olumlu görüşlerine de ulașılmıştır.

Aşağıda bazı dikkat çeken görüşlere yer verilmiştir.

"... Bir öğrenci girmiș derse, sesleniyorum Mustafa orada mısın? Öğrencide ses yok. Derse girmiş ama etkileşim yok. Bunlar olumsuz etkiliyor verimliliği. Öğrenciler şöyle düşünüyor; aman beden eğitimi dersi, ne konuşacağım ben, beden eğitimi dersi hareketli bir ders diye derse girmiyorlar." (L14)

"... Internet tabanlı sorunlar verimliliği düşürdü. Bunu çözdükten sonra öğrencinin de etkin katılımı çok önemli uzaktan eğitimin verimli geçmesi açısından. Öğrenciler etkileşime geçmediğinde ders verimliliği bizim açımızdan çok düşüyor. Sanki boş bir ortama kendi kendime ders işliyor gibi hissediyorum." (012) 
"... Dersin en verimsiz geçmesini sağlayan unsur çocukların derse düzensiz katılması oldu. Çünkü her hafta birbirinin üstüne koyabileceğimiz teorik bilgiler verdiğimiz için çocuk bir önceki hafta katılmayınca ertesi hafta eksik kaldı. O yüzden en büyük sıkıntı öğrenci devamsızlığı problemiydi." (L10)

"... Daha sonra çocukların kameralarını açmaması da bir problem çocuklarla karşılıklı göz teması kuramiyoruz biz ekrana bakarak ders anlatmak zorunda kalıyoruz. Karşımızda insan var mı yok mu bunun psikolojisi bizi olumsuz anlamda etkiliyor." (L8)

"... Kameralar açık olmadığından çocuk karşımızda değil karanlıkta bir yerlere ders anlatıyormuşuz gibi sıkıntılar var fakat kamerası olup açmayanlar için hiç hoş değil." (05)

"... Bizim dersiniz uygulamaya dönük yaparak yaşayarak öğrenmeye dayalı bir ders ve uzaktan eğitimle biz uygulamayı çok fazla yerine getiremiyoruz; bu bakımdan verimsiz. Getirmeye kalktığımızda ise öğrencinin fiziki şartının ne olduğunu bilemediğimiz için ya da hareketi uygulatacă̆ımı etkinliği doğru yapıp yapmadıklarını bilmediğimiz için çok fazla yapamıyoruz. Hatta ısınma hareketlerini yaptırırken bile endişe edebiliyoruz çünkü çocuklar yanlış bir şey yapıp kendisine zarar verir mi diye düşünüyoruz." (02)

"... Yine de bu süreçte takibini yapmak zor ayrıca bazılarının interneti olmuyor derse giremeyen ya da internet kotası olmayan öğrenciler gibi bir sürü olumsuz yanı var." (L4)

"... Başka bir problem olarak evde üç dört kardeş olan çocuklar kardeşi derse girdiğinde bir diğeri giremiyor. Anne babası öğretmen olan çocuklarda aynı şekilde derse girdiğinde yine çocuk için sıkıntı oluyor. Bir ailenin beş tane bilgisayar alması maddi anlamda zor olacağı için süreç sorunlu ve verimsiz devam ediyor." (L8)

"... Uzaktan eğitim sistemine geçileceği zaman hiçbir şeyden haberimiz olmadığı için çok hazırlıksız yakalandık. Teknolojik olarak uzaktan eğitime yönelik ders içeriği hazırlama konusunda da yetersizdik. Birçok arkadaşımız Zoom kullanmayı bilmiyordu bu konularla ilgili bilgi sahibi olsaydık daha iyi olurdu." (011)

"... Öncelikle öğretmen arkadaşlarımıza Zoom (görüntülü iletişim uygulaması) ve Eğitim Bilişim Ă̆ı [EBA] gibi programlar hakkında geniş bir bilgi verilmemişti. Bizler deneme yanılma yoluyla bu programları öğrenmeye başladık." (05)

"... Genel anlamda uzaktan eğitim kısmen verimli oldu diyebiliriz. Mesela biz beden eğitimi dersini okullarda uygulamalı olarak işliyoruz, dolayısıyla öğrenciler işin teorik kısmından uzak kallyorlar. Ama uzaktan eğitimle çeşitli spor branşları ile az bilinen spor branşlarını tanıtma firsatı ve kurallarını öğretme firsatı bulduk. Yani uzaktan eğitim teorik konuların aktarımında verimli olduğunu söyleyebilirim. Tabi bizim dersimiz uygulamalı bir ders bir yere kadar bunu yapabiliyorsunuz. Bir yerden sonra kısır bir döngüye giriyor." (L9) 
Tablo 3. Uzaktan eğitimde beden eğitimi ve spor dersinin verimliliğini arttırmaya yönelik gerçekleștirilen uygulamalara ilişkin öğretmen görüşleri

\begin{tabular}{|c|c|c|c|c|}
\hline Tema & Alt Tema & Kod & Katılımcı & $f$ \\
\hline \multirow{12}{*}{$\begin{array}{l}\text { Uzaktan eğitimde } \\
\text { ders verimliliğini } \\
\text { arttırmaya } \\
\text { yönelik } \\
\text { uygulamalar }\end{array}$} & \multirow{5}{*}{$\begin{array}{l}\text { Ders } \\
\text { içeriklerine } \\
\text { iliş̧kin }\end{array}$} & Video destekli & 01, 02, L4, L6, 07, 011, L14 & 7 \\
\hline & & Görselleștirme & $01,02,03, \mathrm{~L} 6$ & 4 \\
\hline & & Egzersize dayalı & L4, O7, 011, 012 & 4 \\
\hline & & Teorik tabanlı & $\mathrm{O} 3, \mathrm{~L} 4, \mathrm{~L} 6, \mathrm{O} 13$ & 4 \\
\hline & & Toplam & & 19 \\
\hline & \multirow{3}{*}{$\begin{array}{l}\text { Öğrenci } \\
\text { katılımına } \\
\text { ilișkin }\end{array}$} & Etkin katılım & 01, 03, L6, 07, L8, 012 & 6 \\
\hline & & Devamsızlık takibi & L4, L9 & 2 \\
\hline & & Toplam & & 8 \\
\hline & \multirow{4}{*}{$\begin{array}{l}\text { Öğretmene } \\
\text { iliş̧in }\end{array}$} & Zümre işbirliği & 03, L4, L6, 07 & 4 \\
\hline & & Kursa katılım & L9 & 1 \\
\hline & & Toplam & & 5 \\
\hline & & Genel toplam & & 32 \\
\hline
\end{tabular}

Tablo 3'de görüldüğü gibi "uzaktan eğitimde ders verimliliğini arttırmaya yönelik uygulamalar" teması yer almaktadır. Bu tema altında "ders içeriklerine ilişkin", "öğrenci katılımına ilişkin" ve "öğretmene ilişkin" üç alt temaya ulaşılmıştır. Öğretmen görüşleri neticesinde uzaktan eğitimde beden eğitimi ve spor derslerinin verimliliğini arttırmaya yönelik gerçekleştirilen uygulamaların çoğunun "ders içeriklerine ilişkin" alt temada yer alan "video destekli" (derslerin youtube vb. kanallar yardımıyla işlenmesi), görselleștirme (slayt ve sunu hazırlanması ve izletilmesi), "egzersize dayalı" (dersin uygulamalı bölümlerinde daha çok egzersiz yaptırılması) ve "teorik tabanlı" (dersin genelinin teorik yani oyun kurallarının, yeni spor branşlarının ve milli sporcuların anlatımı şeklinde işlenmesi) kodlarından oluştuğu tespit edilmiştir. Ayrıca öğrenci katılımına ilişkin alt temada "etkin katılım" ve "devamsızlık takibi" ile öğretmene ilişkin alt temada "zümre işbirliği" ve "kursa katılım" (uzaktan eğitim, dijital içerik üretme vb.) kodlarına ulaşılmıştır. Aşağıda bazı dikkat çeken görüşlere yer verilmiştir.

"Dersi biraz daha interaktif değerlendirip derste daha verimli hale getirdiğimi düşünüyorum. YouTube'da çok güzel içerikler var. Bu kaynaklardan faydalanıyorum." (07)

"... Videolar ve sunumlar hazırlayarak dersi verimli hale getirmeye çalıștım. Benim normalde beden eğitimi dersinde her zaman hayal ettiğim bir șey vardı bunun bir tarafı okulda bir tarafi ise internet ortamındaydı. Fakat tam olarak yapamiyorduk. Cocuklara uygulamalı aktardığımız konuların teorik bölümlerini bilgisayar ortamı içerisinde bilişim sınıfinda sunu ve videolarla görselleştirmeye yönelik çeşitli fikirlerim vardı. İşte tam da uzaktan eğitim sürecinde bunu yapmaya çalıștım. Kendi açımdan verimliliği artırmak için teorik konuları görsel sunumlar ile pekiştirerek derslerde sunmaya çalıştım." (L6)

"... Uzaktan eğitim dersinden sonra bütün sınıflara egzersiz yaptırdım. İlk önce 1 saatti derslerimiz sonra ders 2 saate çıkarıldı. 2 saatin 1 saatini egzersiz yaparak geçirdim." (011)

"... Daha çok teorik konuları işlemek zorunda kaldığım için ne yapabilirim diye düşündüm. Türkiye'den ve dünyadan önemli sporcuların hayatları ile ilgili mesela fair play ödülü almış sporcularla ilgili slaytlar hazırladım beraberinde farklı spor dalları mesela hiç duymadıkları körling, motor sporları, buz pateni ve daha çok ekstrem spor dalları var onlarla 
ilgili çeşitli sunumlar ve videolar hazırladım olimpiyatlarla ilgili çok sunum hazırladım yani en azından çocukların sıkılmasını önlemeye çalıştım." (03)

"... Öğrenciyi birebir işin için katarak, örnek vermek gerekirse; Çocuklara bir spor branşında sunum hazırlama ödevi verdim. Her ders üç dört kişi, yedi sekiz dakikalık sunum yapıyorlar. Bu şekilde öğrenciyi derse daha çok katarak verimli hale getirmeye çalışıyoruz çünkü anlatım boyutu öğrenciyi sıkan bir boyut. Zaten çok tavsiye edilen bir yöntem de değil. Bu yüzden çocukları biraz daha derse katarak uzaktan eğitim sürecini verimli hale getirmeye çalışlyorum." (01)

"... Öğrenciler beden eğitimi dersi saatlerini dinlenme saatleri olarak kullanmaya çalışıyorlar. Biz elimizden geldiğince yoklama falan alıyoruz bu şekilde derse devamlarını ve ders verimliliğini sağlıyoruz. Bunu yapmazsak çocukların büyük kısmı derse girmiyor. Ben bir şekilde çocukları derse dâhil etmeye verimi sağlamaya çalıştım." (L9)

"... Beden eğitimi öğretmeni arkadaşlarla konuşuyorum. Kimisi ben slâyt yapıyorum öğrencilere veriyorum, kimisi ben video izletiyorum, diğeri kurallarl, saha bilgilerini işliyorum diyor. Yani dersin verimliliği için sürekli işbirliği halinde paylaşımda bulunuyoruz." (L4)

"... Bütün dünya çok hazırlıksız yakalandı. Açıkçası ben ben Milli Eğitim Bakanlı̆̆ı'nın [MEB] bu noktada iyi bir sınav verdiğini düşünüyorum. Tabii ki bunun hazırlı̆̆ı önceden yapılsaydı daha iyi olurdu. EBA sistemi üzerinden öğretmenlere uzaktan eğitim yeterliklerini arttırmaya yönelik eğitimler verildi. Ben bu kurslara katılarak uzaktan eğitim derslerinde yeterliklerimi arttırarak verimliliği arttırmaya çalıştım. " (L9)

Tablo 4. Yüz yüze ve uzaktan eğitimin tercih edilme durumlarına ilişkin öğretmen görüşleri

\begin{tabular}{|c|c|c|c|c|}
\hline Tema & Alt Tema & Kod & Katılımcı & $f$ \\
\hline \multirow{10}{*}{$\begin{array}{l}\text { Yüz yüze } \\
\text { ve uzaktan } \\
\text { eğitiminin } \\
\text { tercih } \\
\text { edilme } \\
\text { durumları }\end{array}$} & \multirow{6}{*}{$\begin{array}{l}\text { Yüz yüze } \\
\text { eğitimi tercih } \\
\text { nedenleri }\end{array}$} & Uygulama yapılabilirlik & $\begin{array}{l}\text { 01, 02, O3, L4, 05, L6, 07, } \\
\text { L8, 012, } 013\end{array}$ & 10 \\
\hline & & Gözlem yapılabilirlik & L4, O7, L8, 011 & 4 \\
\hline & & Geri dönüt verilebilirlik & 02, 03, L6, 011 & 4 \\
\hline & & Öğrenci isteği & 01, L4, 05 & 3 \\
\hline & & Motivasyon sağlaması & L14 & 1 \\
\hline & & Toplam & & 22 \\
\hline & \multirow{3}{*}{$\begin{array}{l}\text { Uzaktan eğitimi } \\
\text { tercih nedenleri }\end{array}$} & Pandemi sürecine uygunluk & 02, L8, L9 & 3 \\
\hline & & Hibrit modele uyum & L10 & 1 \\
\hline & & Toplam & & 4 \\
\hline & & Genel toplam & & 26 \\
\hline
\end{tabular}

Tablo 4'te görüldüğü gibi "yüz yüze ve uzaktan eğitimin tercih edilme durumları" teması yer almaktadır. Bu tema altında "yüz yüze eğitimi tercih nedenleri" ve "uzaktan eğitimi tercih nedenleri" olmak üzere iki alt temaya rastlanmıştır. Öğretmen görüşleri neticesinde büyük çoğunluğu yüz yüze eğitimin tercih nedenleri alt temasında yer alan "uygulama yapılabilirlik", "gözlem yapılabilirlik", "geri dönüt verilebilirlik, "öğrenci isteği" ve "motivasyon sağlama" kodlarından oluşmaktadır. Bazı öğretmen görüşleri neticesinde uzaktan eğitimi tercih nedeni alt temasında yer alan "pandemi sürecine uygunluk" ve 
"hibrit modele uyum" kodlarına da rastlanmıştır. Pandemi sürecinde bulaş olasılığını azaltması ve de yüz yüze eğitimin kesintiye uğradığı süreçte uzaktan eğitimin gereklilik olduğu yönünde öğretmen görüşleri yer almaktadır. Bununla birlikte uzaktan eğitimin, hibrit eğitim modeline uyum sağlama bakımından önem ifade ettiği şeklindeki bir öğretmen görüşü de tespit edilmiştir. Așağıda bazı dikkat çeken görüşlere yer verilmiştir.

"... Tabi ki yüz yüze eğitimi tercih ederim. Özellikle kendi dersimiz açısından, diğer dersler biraz daha anlatıma dayalı ama bizimki tamamen yaparak yaşayarak öğrenmeye dayalı bir derstir. Ve öğrenciler tarafından uygulama kısmının sevilmesi sağlık ve psikolojik bakımdan öğrenciler için faydalıdır. Bu dönemde uygulamalı derslerden yoksun olduğumuz için, yüz yüze eğitim tercih ettiğimiz eğitimdir”. (01)

"... Tabii ki yüz yüze eğitimi tercih ederim. Çünkü hem çocukları birebir görüp daha iyi iletişim kurabiliyoruz. Ayrıca yüz yüze eğitimde nerede hata yaptıklarını ya da nerede eksikleri olduğunu fark edip gözlemleyebiliyor sonrasında çocuklara geri dönütler sağlayabiliyoruz. Ama uzaktan eğitimde maalesef bunların hiçbirini yapamadık." (011)

"... Yüz yüze eğitimi tercih ediyorum. Yaparak, yaşayarak, hissederek, dokunarak yani yerinde öğrenerek işte hatalara yapılan yanlış hareketlere yerinde müdahale ederek sorunu temelden halletmeye özetle geri dönüt verebilme bakımında tercih ediyorum. Zaten biliyorsunuz beden eğitimi ve resim gibi uygulamaya dönük derslerde öğrenci yanlış bir şey öğrendiği zaman onu düzeltmek çok zor oluyor o yüzden yanlışlara anında müdahale edebilmek bizim için çok büyük bir avantaj oluyor." (02)

"... Uzaktan beden eğitimi dersinde öğrenciler de pes etti. Bunun bu şekilde verimli olabilme şansı mümkün değil. Hatta çocuklara yüz yüze eğitime geçmek mi istersiniz yoksa böyle mi devam edelim dedik 25 kişilik sınıftan beş kişi böyle devam edelim dedi 20 tanesi hemen okula dönmek istedi. Öğrencilerimiz acil yüz yüze eğitimi istiyor." (05)

"... Beden eğitimi konusunda kesinlikle yüz yüze eğitimi seçerim. Yüz yüze de motivasyon var. Tabi öğrenci bunu ekrandan da görebilir ama hocasının yaptığını görünce çocuk daha motive oluyor. Bunları görüp, hissetmek çok özel bir durumdur. Uzaktan eğitimle bilgisayar karşısında beden eğitimi dersi işlemek dersin doğasına uygun değil. Öğrencileri bilgisayardan motive edemiyoruz, sadece yüz yüze de bu mümkün." (L14)

"... Çok verimli olduğunu düşünmüyorum. Fakat ülkemizin yaşadığı bu pandemi şartlarında bu süreç gerekli aynı zamanda uzaktan eğitim bir nimet ve öğrenciye ulaşma bakımından gerekli." (02)

"... Ben şunu gördüm yüz yüze eğitimin yanında mutlaka bizler uzaktan eğitimle de teorik olarak dersleri desteklemeliyiz. Yani okulda sadece uygulamalı olarak gösterdiğimiz zaman teorik bilgi gerçekten eksik kallyor ama bu ikisini beraber birlikte yürütebilmek iyi olabilir diye düşünüyorum. Gelecekte eğitimde hibrit modele geçilmesi düşünülürse bu bakımdan uzaktan eğitim, hibrit modele uyum sağlamamızda önemlidir." (L10) 
Tablo 5. Uzaktan eğitimle yürütülen beden eğitimi ve spor dersine yönelik talep ve önerilere ilişkin öğretmen görüşleri

\begin{tabular}{|c|c|c|c|c|}
\hline Tema & Alt Tema & Kod & Katılımcı & $\boldsymbol{f}$ \\
\hline \multirow{18}{*}{$\begin{array}{l}\text { Uzaktan } \\
\text { eğitime } \\
\text { yönelik } \\
\text { talep ve } \\
\text { öneriler }\end{array}$} & \multirow{5}{*}{$\begin{array}{l}\text { Öğretmene } \\
\text { ilişkin }\end{array}$} & BİT eğitimi & $\begin{array}{l}\text { 01, 03, L4, 05, L6, 07, L8, L9, L10, } \\
\text { 011, 012, 014 }\end{array}$ & 12 \\
\hline & & Oryantasyon & $\begin{array}{l}\text { 02, L4, 05, L6, 07, L8, L9, L10, 012, } \\
\text { L14 }\end{array}$ & 10 \\
\hline & & Ortak bilgi havuzu & 02, L4, 05, L6, 07, L8, L10 & 7 \\
\hline & & Sınıf yönetimi & 012 & 1 \\
\hline & & Toplam & & 30 \\
\hline & \multirow{6}{*}{ Derse ilişkin } & Müfredatın uyarlanması & 03, L4, 05, L8, L9, L10, 011, L14 & 8 \\
\hline & & $\begin{array}{l}\text { Ders ortamlarının } \\
\text { iyileștirilmesi }\end{array}$ & $02,011,013$ & 3 \\
\hline & & Doküman eksikliği & 02,012 & 2 \\
\hline & & Sinav notu verilmeli & 02, L6 & 2 \\
\hline & & Sinav notu verilmemeli & 01,03 & 2 \\
\hline & & Toplam & & 17 \\
\hline & \multirow{3}{*}{$\begin{array}{l}\text { Öğrenciye } \\
\text { ilişkin }\end{array}$} & $\begin{array}{l}\text { Aktif katılımları } \\
\text { sağlanmalı }\end{array}$ & 01, L6, L9, L10, 013, L14 & 6 \\
\hline & & Bilinçlendirilmesi & 01, L14 & 2 \\
\hline & & Toplam & & 7 \\
\hline & \multirow{4}{*}{ Veliye ilişkin } & Velilerin bilinçlendirilmesi & 02, 013, L14 & 3 \\
\hline & & Velilerin dahil edilmesi & 013 & 1 \\
\hline & & Toplam & & 4 \\
\hline & & Genel toplam & & 59 \\
\hline
\end{tabular}

BİT: Bilgi iletişim teknolojileri

Tablo 5'te görüldüğü gibi "uzaktan eğitime yönelik talep ve öneriler" teması yer almaktadır. Bu tema altında "öğretmene ilişkin", "derse ilişkin", "öğrenciye ilişkin" ve son olarak "veliye ilişkin" olmak üzere dört alt temaya rastlanmıştır. Öğretmen görüşlerinin büyük çoğunluğunu öğretmene ilişkin alt temada yer alan "Bilgi iletişim teknolojileri eğitimi", "oryantasyon", "ortak bilgi havuzu" ve "sınıf yönetimi" kodlarından oluştuğu görülmektedir. Bununla birlikte derse ilişkin alt temada "müfredatın uyarlanması"; öğrenciye ilişkin alt temada, "aktif katılım"; veliye ilişkin alt temada ise "velilerin bilinçlendirilmesi" kodlarına sıklıkla rastlanmıştır. Derse ilişkin alt temada uzaktan eğitimle yürütülen derslerde not ile değerlendirmenin yapılıp yapılmaması konusunda bazı öğretmen görüşlerinin farklılaștığı tespit edilmiştir. Aşağıda bazı dikkat çeken görüşlere yer verilmiștir.

"... Teknolojik altyapı nasıl kullanılır bu noktada öğretmenlerimizin bilgi iletişim teknolojilerini nasıl daha aktif bir şekilde kullanabilecekleri ile ilgili bir çalışmanın olmasını isterdim. Bunun dışında kendi branşım iç̧in hangi eğitimler ne gibi çalışmalar beden eğitimi dersinde daha verimli olur ve bununun örnekleriyle beraber verilmesini isterdim." (L9)

"... Bilgi iletişim teknolojileri kapsamında bazı platformları kullandık Zoom ve Google meeting gibi. Ísimlerini duymadığımız birçok platformdan ders anlatmaya çalıştık. Bunların tanıtımına yönelik eğitimler olmalı." (L10) 
"... Eğer ki bir oryantasyon eğitimi verilmiş olsaydı biz de hazırlıklarımızı ona göre yapardık. Yani en başında bu sürece ilişkin yapılması gerekenlerle ilgili bir ön hazırlık edinseydik bocalamazdık. Sadece beden eğitimi değil diğer branşlar için de faydalı diye düşünüyorum." (012)

"... Karşımızda öğrenciyi göremediğimiz için öğrencinin tepkisini bilemiyorsunuz. Ben dersi anlattıktan sonra anladınız mı çocuklar diye soruyorum öğrenciden bir tepki gelmediğ i zaman bu sefer diyorsunuz ki ben havanda su mu dövüyorum ben ne iş yaplyorum. Iște bu yüzden bütün bu süreçleri yönetmeye yönelik öncesinde bir oryantasyon eğitimi verilseydi çok etkili olurdu." (L6)

"... Uzaktan eğitim sürecinde zümremiz açısından bir birliktelik ne yazık ki Türkiye genelinde asla yok. Herkes kendi başına bir şeyler yapmaya, kurcalamaya çalışıyor. Ortak bir platform veya bilgi merkezi oluşturulabilirdi." (07)

"... Öncelikle bu programı hazırlayanlar öğrenciyi derse katmayı tasarlamalı. Bunun sonrasında bir bilgi havuzu oluşturulabilir hepimiz oraya oluşturduğumuz kaynakları slâytları atıp bütün öğretmenlerin faydalanmasını sağlayabiliriz." (L10)

"... Bir de müfredata bağlı kaldığınız zaman bu süreçte biraz sıkıntı oluyor. Müfredatta futbol varsa evde nasıl futbol işleyeceksiniz ya da basketbol nasıl işleyip nasıl göstereceksiniz. Bundan ziyade daha çok evde çocukların yapabilecekleri hareketlerle ilgili bir planlama yapılması iyi müfredatın ve içeriğin uyarlanması, planlanması iyi olurdu." (L4)

"... Dersin uzaktan eğitimle işlenebilmesi için çeşitli yöntemler tasarımlar var bunlar hakkında beden eğitimi öğretmenleri yetiştirilmelidir. Biz de ders içeriklerimizi o yönde çeşitlendirebiliriz, uyarlayabiliriz. Şuan kendimiz bir şeyler yaparak, deneyerek ve yanılarak bir şeyler bulmaya çalışıyoruz. Fakat bakanlığımızın bu konuya el atması önemli olacaktır." (L8)

"... Çocukların odalarının çok dar olduğunu gördüm. Ben o ortamda çocuklara egzersiz yaptırmaya çalıştım. Cocukların evdeki ortam sınırlılığından dolayı dersimize uygun değildi uzaktan eğitim." (011)

"... Değerlendirme noktasında ben değerlendirme olmasını tercih ederim. Ders içi katılım notunun olmasını kabul ederim şu andaki gibi. Aksi halde dersimize olan bakış açısı değer kaybedecek. Velilerin bu derse çok fazla önem verdiğini düşünmüyorum. Biz öğrenciye sadece fiziki olarak değil duygusal olarak da etkiliyoruz. Bu sebeple not sisteminin olmasını tercih ederim. Aksi halde katılım olmayacak." (02)

"... Benim şahsi fikrim bu süreçte beden eğitim, resim ve müzik derslerinden not olayının olmaması gerekiyordu. Çocukların ders performanslarına göre değerlendirmek bilgisayar ekranından çocuğun derse katılması demek. Ders içi performans notu vereceğim ama çocuğun derse girme zorunluluğu da yok. Yani bunların sıkı kurallar ve iyi alınmış kararlar ile net bir şekilde belirlenmesi gerekiyor." (03)

"... Uzaktan eğitimde derslerime katılım \%10-20 civarında üç beş kişiyle ders yaptığım oluyor. Otuz kişilik sınıfta en fazla oniki onüç kişiyle ders işledim onlarda aktif değiller. 
Çocuklar menfaat uğruna, not uğruna derse giriyor öğrenmek için değil. Öğrencilerin aktif katılımlarını sağlayacak çözümler bulunmalı." (L6)

"... Beden eğitimi dersinin ve bunun yanında resim, müzik ve teknoloji tasarım gibi derslerin önemsiz görülmemesi ile ilgili öğrencilere bir eğitim verilmesi, onların bilinçlendirilmeleri güzel olurdu. Uzaktan eğitim sürecinden de aynı durum var. Sadece lise sınavında soru çıkan dersler önemseniyor. Öğrenciler bilinçlendirilmeli. Ülke olarak ne kadar önemli bir ders olduğunu anlamış değiliz." (01)

"... Ayrıca veliler de dersleri önemsemiyor, çocuklarının üstüne düşmüyorlar ders konusunda. Aaa beden eğitimi dersi mi var boş ver girme düşüncesindeler. Bunlar öğrencilerin derse karşı olan tutumu, verimliliği olumsuz anlamda etkiliyor. Bundan dolayı velilerin bilinçlendirilmesi çok önemli bir şekilde velilere bu durum aktarılmalıdır." (L14)

"... Ailelerin uzaktan eğitim sürecine dâhil edilmeleri gerekiyor. Ben kendi çocuğumdan örnek vereyim ne yapıyoruz bilgisayarını veriyoruz evet çocuğum ID numarası bu, şifre bu diyerek çocuğu sadece öğretmenle baş başa bırakıyoruz. Beden eğitimi dersi için ben açıkçası velilerle beraber işlenen bir dersin daha yararlı olacağını düşünüyorum. " (013)

\section{Tartışma}

Araştırmada beden eğitimi ve spor dersinin verimliliği açı sından uzaktan eğitim sürecine ilişkin öğretmen görüşlerinin belirlenmesi" amacına ilişkin yapılan görüşmeler sonucunda 4 ana temaya ulaşılmıştır. Bunlar; beden eğitimi ve spor dersinin uzaktan eğitim sürecinin verimliliği, uzaktan eğitimde ders verimliliğini arttırmaya yönelik uygulamalar, yüz yüze ve uzaktan eğitimin tercih edilme durumları ve son olarak uzaktan eğitime yönelik talep ve öneriler şeklindedir.

Araştırmanın ilk teması uzaktan eğitim süreci ile ilgili olarak öğretmen görüşleri incelendiğinde çoğunlukla öğrenci ile ilişkili olarak öğrencilerin derse devam etmedikleri, derse gelenlerin ise etkileşime geçmedikleri ve kameralarını açmadıkları yönünde sonuçlara ulaşılmıştır. Ders verimliliğine ilişkin olarak beden eğitimi ve spor derslerinin uygulama gerektiren konularında uzaktan eğitim süreci verimsiz, teorik bilgilerin aktarıldığı konularda ise bazı öğretmen görüşleri doğrultusunda verimli bulunmuştur. Fırsat eşitsizliği bakımından öğrencilerin internet, tablet, bilgisayar vb. donatılara sahip olmadıkları bulgularına rastlanmıştır. $\mathrm{Bu}$ temada son olarak öğretmenlerin teknopedagojik eğitim yeterlikleri bakımından uzaktan eğitim sürecine hazır olmadıkları ve bu süreçte kullanılan programları (Zoom, EBA vb.) bilmedikleri yönünde bulgulara ulaşılmıștır. Bulgular neticesinde katılımcıların büyük bir kısmı uzaktan eğitim sürecinin verimsiz geçtiğini vurgulamış ve karşılaştıkları olumsuzlukları belirtmişlerdir. $\mathrm{Bu}$ bağlamda uzaktan eğitimin, öğretmenlerin görüşleri doğrultusunda tam olarak benimsenmeyen bir sistem olarak görüldüğü söylenebilir. Bu durumu destekleyen Kurnaz ve Serçemeli'nin (2020) araştırmasına göre; öğretmenlerin COVID-19 salgını sürecinde eğitim ve öğretim hayatının devamı niteliğinde olan uzaktan eğitim sisteminin akademisyenler tarafından çok fazla benimsenmediği saptanmıştır. Öte yandan 
katılımcıların önemli bir kısmının ifadelerine dayanarak pandemi sürecinde beden eğitimi ve spor dersinin sadece teorik bölümleri için verimli geçtiğini söylemek mümkündür.

Araştırmanın ikinci teması uzaktan eğitimde ders verimliliğini arttırmaya yönelik uygulamalara ilişkin öğretmen görüşleri incelendiğinde; çoğunlukla ders içeriklerine ilişkin uygulamalar yapıldığı devamında öğrencilerin derslere katılımını arttırmaya yönelik ve beden eğitimi öğretmenlerinin işbirliği, bilgi paylaşımlarına yönelik uygulamalar yapıldığı sonuçlarına ulaşılmıştır. Öğretmenlerin video ve görsel sunulardan faydalanarak ders içeriklerini uzaktan eğitime uygun olarak zenginleștirme yoluna gittikleri, derslerde farklı geleneksel spor dalları ile yeni spor branşlarının tanıtılması gibi güncel ve teorik konulara ağırlık verdikleri tespit edilmiştir. Benzer bir çalışmanın sonuçlarında ders verimliliğinin artırılması için; öğretmen-veli iletişimin artırılması, internet ve teknolojik materyaller ile desteklenmesi ve öğrencileri motive edecek zengin içeriklerin geliştirilmesi yer almaktadır (Koçoğlu ve Tekdal, 2020). Her iki çalışmanın da bulguları, verimliliğin artırılması için birbiriyle tutarlı sonuçlar vermektedir. Araştırmada bazı katılımcılar ise fiziksel aktivite uygulamalarına ağırlık vermişlerdir. Bunun nedeni olarak, kısıtlamalar nedeniyle öğrenci yaşamlarında fiziksel etkinliklerin yok denecek kadar azalması olduğu düşünülebilir. Alanyazında; kısıtlamalar ile birlikte hareketsizliğin de arttığı pandemi sürecinde bireysel uygunluk ve uzman tavsiyesine uyulması hususlarına dikkat edilerek bireylerin evde, mümkünse açık alanlarda egzersizlere devam etmesinin önemi vurgulanmaktadır (Çelik ve Yenal, 2020). COVID-19 salgını sürecinde öğrencilerin beden eğitimi ve spor etkinlikleri yanı sıra egzersizden ve spordan uzak kalmalarının nedeni olarak, ailenin bulaş riski endişesiyle korumacı yaklaşımlarından kaynaklandığı düşünülebilir. Alan yazında öğrencilerin egzersize katılımlarında engel olarak ebeveynlerin aşırı korumacı yaklaşımlarını vurgulayan araştırma bulguları bunu destekler niteliktedir (Çetin, Demir, Göloğlu ve Levent, 2020).

Araştırmanın üçüncü teması yüz yüze ve uzaktan eğitiminin tercih edilme durumlarına ilişkin öğretmen görüşleri incelendiğinde; katılımclların büyük çoğunluğunun yüz yüze eğitimi tercih ettikleri sonucuna ulaşılmıştır. Çünkü beden eğitimi derslerinin uygulama gerektirmesi ve uzaktan eğitim ile uygulamalı konuların öğretiminin mümkün olamayacağı, yüz yüze eğitimin ders esnasında gözlem yapmaya, öğrenciye geri dönüt vermeye olanak sağlaması ve öğrencilerin de yüze yüze eğitimi tercih etmeleri gibi nedenlerden dolayı öğretmenlerin yüz yüze eğitimi tercih ettikleri sonuçlarına ulaşılmıştır. Alan yazında uzaktan veya yüze eğitimin tercih edilmesine ilişkin yapılan diğer çalışmalarda ortaya çıkan sonuçlara bakıldığında; bazı bireylerin uzaktan eğitimi tercih ederken diğerlerinin ise yüz yüze eğitimi tercih etmesinde bazı değişkenler mevcuttur. Bunlar; öğretme tekniği, öğretmenin karakteri ve öğrenen bireylerin karakteri doğrultusunda değişmektedir (Zhao, Lei, Yan, Lai ve Tan, 2005). Ekiz (2020) ise; uzaktan eğitimin esnek ve rahat yapısından dolayı öğrenciler tarafından tercih edilen bir sistem olduğu, ancak derslerin daha etkili olabilmesi için teknik aksaklıkların azaltılması, öğretmen-öğrenci iletişiminin sağlıklı şekilde gerçekleştirilmesi gerektiğini vurgulamaktadır. Aynı zamanda Karal, Çebi ve Turgut'a göre (2011); öğrencilerin uzaktan eğitimde işlenen derslere karşı bazı olumsuz tutumları bulunmaktadır. Bu tutumlar 
arasında; iletişimin sağlanamaması, göz kontağının yetersiz olması, görüntü ve ses ile ilgili problemlerin meydana gelmesi, beraberlik hissinin olmaması, öğretmenin zayıf kontrolü ve her zaman ulaşmanın mümkün olmaması gibi unsurlar yer almaktadır. Öğrencilerin uzaktan eğitime karşı olumlu tutumları ise; bilgiye her zaman hızlı erişimlerinin olması, uzmandan yararlanma, daha esnek davranabilme ve kayıtlı dersleri tekrar izleyebilme olanaklarını kapsamaktadır. Spor bilimleri fakültesinde öğrenim gören öğrencileri kapsayan farklı bir çalışmada ise öğrencilere izolasyon süreci olmasaydı uzaktan eğitimi isteyip istemeyecekleri sorulmuş ve $\% 76,5$ çoğunlukta öğrenciler uzaktan eğitim ile ders işlemek istemediklerini belirtmişlerdir (Aktaş, Büyüktaş, Gülle ve Yıldız 2020). Araştırmanın bu temasında bazı öğretmenlerin hastalık süresince bulaşı önlemesi ve de uzaktan eğitimin yapılamaması durumlarında öğrenci ile birlikteliğin sağlanması bakımından uzaktan eğitimi bir gereklilik ve firsat olarak görmektedirler. Bununla birlikte geleceğin eğitim sisteminin hibrit eğitim modeli ile yürütülme olasılığı göz önüne alınırsa uzaktan eğitimin bu sürece bir hazırlık olması bakımından önemli olduğu yönünde öğretmen görüşüne de ulaşılmıştır. Bu bakımdan alanyazında bu araştırmanın bulguları ile örtüşen şu sonuçlara ulaşılmıştır. Qu'a (2018) göre sporda uzaktan eğitim ile derslerin işlenmesi sadece yüz yüze eğitimi desteklemez aynı zamanda uzun vadede modern beden eğitimi ve spor dersi için yeni bir çıkış yolu sunmaktadır. Bununla birlikte teknolojinin geliştirilmesi ve öğretmenlerin uzaktan eğitime ilişkin bilgilerinin artması; salgın döneminde uzaktan eğitim ile eğitime devam edilebilmesinde ve teması engelleyerek bulaşı engellemesi bakımından bir rol oynamaktadır (Liu, Zhou, Chen, Yang ve Tan, 2020).

Araştırmanın son temasında uzaktan eğitime yönelik talep ve öneriler, öğretmen görüşleri incelendiğinde öğretmen, ders, öğrenci ve veliye ilişkin bulgulara rastlanmıştır. Öğretmenler çoğunlukla uzaktan eğitimle ilgili olarak; bilgi iletişim teknolojilerine ilişkin eğitim gereksinimlerinden, uzaktan eğitime geçilmeden önce bununla ilgili olarak oryantasyon yapılması gerekliliğinden, öğretmenler arasındaki uygulamalardaki farklılıkların en aza indirilmesi için zümre işbirliği, ortak bilgi havuzu platformlarının oluşturulması yönündeki talep ve önerilerinden bahsetmektedirler. Bulgular neticesinde öğretmenlerin teknopedagojik yeterliklerin arttırılması, Zoom ve EBA gibi programların daha etkili kullanılması için öğretmenlere hizmet içi eğitimlerin verilmesi ve öğretmenlerin sürekli desteklenmeleri önem arz etmektedir. Alan yazında benzer şekilde Milli Eğitim Bakanlığı tarafından uzaktan eğitime ilişkin hizmet içi eğitim verilmesi önerisi (Özdoğan ve Berkant, 2020) ve öğretmenlerin teknolojik materyal hazırlama ve dijital okuryazarlık yeterliklerini arttırmaya yönelik eğitimleri almaları (Akgül ve Oran, 2020) önerilmektedir. Qu'nun (2018) çalışmasına göre öğretmenlerin teknoloji açısından bir eğitim almaları ve kullandıkları programlar hakkında iyi bir bilgiye sahip olmaları gerektiği belirtilmiştir. Uzaktan eğitimin çok hızlı bir şekilde gündeme gelmesi, öğretmenlerin tecrübe eksikliğinden kaynaklı olarak endişelenmelerine neden olmuştur. Başlangıçta derslerin uzaktan eğitim ile işlenmesi çeşitli aksaklıkların meydana gelmesiyle sonuçlanırken derslerin verimliliğini de düşürmüştür. Genel anlamda yoğun olarak kullanılan Zoom ve EBA gibi programlara ilişkin bir eğitim alınması durumunda gerek oluşabilecek zaman kaybının önlenmesine gerekse derslerin daha verimli ve aktif geçmesine katkı sağlayacağı düşünülmektedir. Literatürde yer alan bir araştırmaya göre, 
yüz yüze eğitimin daha çok tercih edilmesindeki neden uzaktan eğitim sisteminde öğretmenlerin herhangi bir tecrübelerinin bulunmamasından kaynaklanmaktadır (Hebebci, Bertiz ve Alan, 2020). Bu çalışma sonuçları doğrultusunda, öğretmen ve öğrencilere uzaktan eğitim sistemine ilişkin gerekli eğitim verilmelidir. $\mathrm{Bu}$ sayede öğretmen ve öğrenciler uzaktan eğitim sistemini daha kolay bir şekilde benimseyebilmektedirler. Tüm bunların yanı sıra oryantasyon eğitimi, uzaktan eğitimde öğrencilerin derste tutulması için önemli bir unsur olarak görülmektedir (Arhin ve Wangeri, 2018). Derse ilişkin olarak uzaktan eğitime yönelik beden eğitimi ve spor dersi müfredatının uzaktan eğitime göre uyarlanması, öğrenciler için uygun ders ortamının hazırlanması, uzaktan eğitime ders dokümanlarının yetersizliği ile ilgili talep ve görüşlere ulaşılmıştır. Rasheed'e (2007) göre; uzaktan eğitimde hazırlanan çalışma materyalleri öğrenciler için önem arz etmektedir. Bu nedenle ders için hazırlanan materyallerin öğrenmeyi destekler nitelikte olması halinde, derslerdeki verimin artacağı düşünülmektedir.

Ayrıca uzaktan eğitimle yürütülen derslerde not ile değerlendirmenin yapılıp yapılmaması konusunda bazı öğretmen görüşlerinin farklılaştığı görülmektedir. Sınav notu verilmesi yönünde görüş belirten öğretmenlerin uzaktan eğitim sürecinin verimsizliğinden ve öğrenci katılımının düşük olmasından kaynakladığı; sınav notu verilmesi yönündeki görüşlerin ise öğrencilerin uzaktan eğitim derslerine katılımlarının sınav uygulaması ile arttırılabileceği yönündeki düşüncelerinden kaynakladığı tespit edilmiştir. Öte yandan öğrenciye ilişkin elde edilen bulgular doğrultusunda, öğrencilerin derse karşı motivasyonlarının arttırılmasının gerekliliği ifade edilmektedir. Son olarak velilere ilişkin ise, beden eğitimi ve spor dersi adına bilinç düzeylerinin geliştirilmesi buna bağlı olarak öğrencilere beden eğitimi ve spor dersinin gereksiz bir ders olmadığı, sağlıklı bir hayat için önem arz eden bir ders olduğu düşüncesi veliler tarafından da çocuklara aşılanması önem arz etmektedir. Ayrıca velilerin uzaktan eğitim sürecine dâhil edilmelerinin gerekliliğine ve velilerle işlenen dersin öğrenci için faydalı olacağına yönelik bir öğretmen görüşü bulunmaktadır. Alan yazında çocukların beden eğitimi ve spor dersine katılımlarında velilerin bilinçlendirilmesi önerilmektedir (Atan, İmamoğlu ve İmamoğlu, 2018).

\section{Sonuç ve Öneriler}

Sonuç olarak uzaktan eğitimle yürütülen beden eğitimi ve spor derslerinin etkileşimsizlik, öğrenci devamsızlığı, uygulamalı konuların işlenmesine elverişsiz olması, öğrencilerin bilgisayar tablet ve internet erişimi bakımından farklılıklarının olması, öğretmenlerin uzaktan eğitime hazırlıksız olmaları ve teknopedagojik eğitim yetersizlikleri gibi nedenlerden dolayı verimsiz olduğu sonucuna ulaşılmıştır. Öğretmeler ders verimliliğini arttırmaya yönelik dersleri video ve görsellerle desteklenmesi, öğrencilerin aktif katılımlarını sağlanması, beden eğitimi öğretmenleri ile fikir alışverişi ve işbirliğinde bulunulması gibi uygulamalara başvurmuşlardır. Salgın ve zorunlu haller dışında öğretmenler uzaktan eğitimi tercih etmemektedirler. 
Uzaktan eğitime ilişkin talep ve görüşler doğrultusunda öğretmenlerin teknopedagojik yeterliklerinin arttırılması, müfredatın uzaktan eğitime göre uyarlanması, ders içerik ve materyallerinin bu bakımdan zenginleștirilmesi öğrencilerin aktif katılımını arttırmaya yönelik uygulamaların arttırılması, velilerin beden eğitimi ve spor dersinin önemi ve gerekliliği hakkında bilinçlendirilmesi önerilmektedir.

\title{
Yazar notu:
}

Bu çalışmanın bir kısmı, $4^{\text {th }}$ International Conference on COVID-19 Studies'de sözel bildiri olarak sunulmuştur.

\section{Çıkar Çatışması}

$\mathrm{Bu}$ makalenin yayınlanmasıyla ilgili yazarlar arasında herhangi bir çıkar çatışması bulunmamaktadır.

\section{Yazar Katkıları}

Araştırma Fikri: NBK, MÇ; Araștırma Tasarımı: SB, HÇ; Verilerin Analizi: MÇ, SB, HÇ; Makale Yazımı: HÇ, SB; Eleştirel İnceleme: NBK

\author{
Yazıșma Adresi (Corresponding Address): \\ Hasibe ÇIL \\ Karabük Üniversitesi, Lisansüstü Eğitim Enstitüsü \\ Akşemsettin Mahallesi Kızılırmak Sokak 13/8 Sincan/ANKARA \\ ORCID: 0000-0002-8024-4392 \\ E-posta: hasibeecill@gmail.com
}

\section{Kaynaklar}


1. Adnan, M. ve Anwar, K. (2020). Online learning amid the COVID-19 pandemic: students' perspectives. Online Submission, 2(1), 45-51.

2. Akgül, G. ve Oran, M. (2021). Sosyal bilgiler öğretmenlerinin, ortaokul öğrencilerinin ve öğrenci velilerinin pandemi sürecindeki uzaktan eğitime ilişkin görüşleri. Eğitimde Yeni Yaklaşımlar Dergisi, 3(2), 15-37.

3. Aktaş, Ö., Büyüktaş, B., Gülle, M. ve Yıldız, M. (2020). COVID-19 virüsünden kaynaklanan izolasyon günlerinde spor bilimleri öğrencilerinin uzaktan eğitime karşı tutumları. Sivas Cumhuriyet Üniversitesi Spor Bilimleri Dergisi, 1(1), 1-9.

4. Arhin, V. ve Wang'erı, T. (2018). Orientation programs and student retention in distance learning: The case of university of cape coast. Journal of Educators Online, 15(1), 1-12.

5. Atan, T., İmamoğlu, R. ve İmamoğlu, 0. (2018). Çocukların beden eğitimi ve spor dersine katılımına ebeveynlerin tutumları. Journal of International Social Research, 11(60), 699704.

6. Barriball, K. L. ve While, A. (1994). Collecting data using a semi-structured interview: a discussion paper. Journal of Advanced Nursing-Institutional Subscription, 19(2), 328-335.

7. Beaudoin, M. (1990). The instructor's changing role in distance education. American Journal of Distance Education, 4(2), 21-29.

8. Büyüköztürk, Ş., Kılıç Çakmak, E., Akgün, Ö. E., Karadeniz, Ş. ve Demirel, F. (2018). Eğitimde Bilimsel Araştırma Yöntemleri. Ankara: Pegem Akademi.

9. Chen, T., Peng, L., Yin, X., Rong, J., Yang, J. ve Cong, G. (2020). Analysis of user satisfaction with online education platforms in China during the COVID-19 pandemic. In Healthcare, $8(3), 200$.

10. Creswell, J. W. (2013). Nitel araştırma yöntemleri. Beş yaklaşıma göre nitel araştırma ve araştırma deseni (s.40-50). M. Bütün, (Ed.), Ankara: Siyasal Kitabevi.

11. Çelik, F. ve Yenal, T. H. (2020). COVID-19 ve hareketsiz yaşam. Akdeniz Spor Bilimleri Dergisi, 3(2), 249-259.

12. Çetin, M., Demir, C. G. ve İlhan, L. (2020). Bilim ve sanat merkezi eğitim programına beden eğitimi ve spor etkinliklerinin dâhil edilmesine yönelik ebeveyn görüşleri. Gazi Beden Eğitimi ve Spor Bilimleri Dergisi, 25(4), 365-386.

13. DeVaney, J., Gideon Shimshon, G., Matthew Rascoff, M. ve Maggioncalda, J. (2020). How can universities adapt during COVID-19? https://www.timeshighereducation.com/sites/default/files/how-can-universities adaptcovid19_whitepaper.pdf

14. Dicicco-Bloom ve Crabtree, B. (2006). The qualitative research interview. Medical Education, 40(4), 314-321.

15. Ekiz, M. A. (2020). Beden eğitimi ve spor yüksekokulu öğrencilerinin karantina dönemindeki uzaktan eğitim ile ilgili görüşleri (Nitel bir araştırma). Spor ve Rekreasyon Araştırmaları Dergisi, 2(Özel Sayı 1), 1-13.

16. Hebebci, M., Bertiz, Y. ve Alan, S. (2020). Investigation of views of students and teachers on distance education practices during the coronavirus (COVID-19) pandemic. International Journal of Technology in Education and Science, 4(4), 267-282.

17. Jena, P. K. (2020). Impact of pandemic COVID-19 on education in India. International Journal of Current Research (IJCR), 12(7), 12582-12586.

18. Kallio, H., Pietila, A., Johnson, M. ve Kangasniemi, M. (2016). Systematic methodological review: Developing a framework for a qualitative semi-structured interview guide. Journal of Advanced Nursing, 72(12), 2954-2965. 
19. Karal, H., Çebi, A. ve Turgut, Y. E. (2011). Perceptions of students who take synchronous courses through video conferencing about distance education. Turkish Online Journal of Educational Technology-Tojet, 10(4), 276-293.

20. Koçoğlu, E. ve Tekdal, D. (2020). Analysis of distance education activities conducted during COVID-19 pandemic. Educational Research and Reviews, 15(9), 536-543.

21. Konecki, M. (2020, Kasim). Impact of distance learning on motivation and success rate of students during the covid-19 pandemic. In 2020 43rd International Convention on Information, Communication and Electronic Technology (MIPRO) (pp. 813-817), IEEE.

22. Kurnaz, A., Kaynar, H., Barışık, C. Ş. ve Doğrukök, B. (2020). Öğretmenlerin uzaktan eğitime ilişkin görüşleri. Milli Eğitim Dergisi, 49(1), 293-322.

23. Kurnaz, E. ve Serçemeli, M. (2020). COVID-19 pandemi döneminde akademisyenlerin uzaktan eğitim ve uzaktan muhasebe eğitimine yönelik bakıș açlları üzerine bir araştırma. Uluslararası Sosyal Bilimler Akademi Dergisi, 3, 262-288.

24. Liu, X., Zhou, J., Chen, L., Yang, Y. ve Tan, J. (2020). Impact of COVID-19 epidemic on live online dental continuing education. European Journal of Dental Education, 24(4), 786-789.

25. Miles, M. B. ve Huberman, A. M. (1994). Qualitative data analysis: An expanded sourcebook. London: Sage Publications.

26. Mood, T. A. (1995). Distance education: an annotated bibliography. Englewood, C0: Libraries Unlimited.

27. Moralista, R. ve Oducado, R. M. (2020). Faculty perception toward online education in higher education during the coronavirus disease 19 (COVID-19) pandemic. Universal Journal of Educational Research, 8(10), 4736-4742.

28. Özdoğan, A. Ç. ve Berkant, H. G. (2020). COVID-19 pandemi dönemindeki uzaktan eğitime ilişkin paydaş görüşlerinin incelenmesi. Milli Eğitim Dergisi, 49(1), 13-43.

29. Pierre, P. S. (1998). Distance learning in physical education teacher education. Quest, 50(4), 344-356.

30. Qu, C. (2018). Application of network technology in distance education of physical education and sport curriculum-take the football course as an example. Educational Sciences: Theory and Practice, 18(5), 2354-2362.

31. Rasheed, F. (2007). Factors impeding implementation of web-based distance learning. Aace Journal, 15(3), 315-338.

32. Ural, A. ve Kılıç, İ. (2005). Bilimsel Araştırma Süreci ve Spss ile Veri Analizi. Ankara: Detay Yayıncllı.

33. Wang, C., Liu, L., Hao, X. ve Guo, H. (2020). Evolving epidemiology and impact of nonpharmaceutical interventions on the outbreak of coronavirus disease 2019 in Wuhan, China: Medrxiv.

34. Yıldırım, A. ve Şimşek, H. (2018). Sosyal bilimlerde nitel araştırma yöntemleri. Ankara: Seçkin Yayıncılık.

35. Zhang, W., Wang, Y., Yang, L. ve Wang, C. (2020). Suspending classes without stopping learning: China's education emergency management policy in the COVID-19 outbreak. Journal of Risk and Financial Management, 13(3), 55.

36. Zhao, Y., Lei, J., Yan, B., Lai, C. ve Tan, S. (2005). What makes the difference? A practical analysis of research on the effectiveness of distance education. Teachers College Record, 107(8), 1836-1884. 